\title{
Interaction of the 89K Murine Cytomegalovirus Immediate-Early Protein with Core Histones
}

\author{
KONRAD MÜNCH, GÜNTHER M. KEIL, MARTIN MESSERLE, AND ULRICH H. KOSZINOWSKI ${ }^{1}$ \\ Federal Research Center for Virus Diseases of Animals, D-7400 Tubingen. Federal Republic of Germany
}

Received July 21, 1987, accepted November 10, 1987

\begin{abstract}
The conditions that permit the interaction of immediate-early proteins of murine cytomegalovirus (MCMV) with DNA were studied. Chromatography of extracts from infected cells on MCMV DNA cellulose and calf thymus DNA cellulose showed that $\mathrm{pp89}$, the regulatory major immediate-early protein, interacts with DNA and dissociates at salt concentrations between 0.3 and $0.6 \mathrm{M} \mathrm{NaCl}$. pp 76, a cleavage product of pp89, and additional minor ie1 proteins eluted already at low ionic strength. Cellular DNA-binding factors were required for association of pp89 with DNA. These factors were identified as core histones. Chromatography of IE proteins on histone-Sepharose in the absence of DNA revealed a high-binding affinity that was resistant to $2 \mathrm{M} \mathrm{NaCl}$. These results suggest that pp89 has no direct DNA-binding activity. A role for an amino acid sequence homology in the $\mathrm{N}$-terminal region of $\mathrm{pp} 89$ with histone $\mathrm{H} 2 \mathrm{~B}$ in the pp89-histone-DNA interaction is discussed. 1988 Academic Press, inc.
\end{abstract}

\section{INTRODUCTION}

The infection of the mouse with murine cytomegalovirus (MCMV) serves as a model to study the biology of cytomegalovirus infection. The genome of MCMV is a double-stranded linear DNA molecule of about 235 $\mathrm{kbp}$ (Ebeling et al., 1983). As with other herpesviruses, gene expression of MCMV is regulated in a cascade fashion (Keil et al., 1984). After infection, immediateearly (IE) genes are the first viral genes expressed. IE proteins are required for the transcription of early genes. MCMV IE genes, IE transcripts, and IE proteins have been characterized (Keil et al., 1985, 1987a,b). Three transcription units (ie 1, ie2, and ie3) clustered in a region of about $12 \mathrm{kbp}$ could be identified. Transcription from ie1 is predominant. The primary transcript is differently spliced to produce a series of related mRNAs. Most abundant is a 2.75-kb mRNA encoding a protein of 595 amino acids with a calculated molecular mass of 66,713 Da. Because this phosphorylated protein migrates in SDS-polyacrylamide gels at an apparent molecular mass of $89,000 \mathrm{Da}$, it has been termed pp89.

Trans-Activation of promoters was detectable after transfection of ie 1 in transient gene expression assays as well as in stably transfected cell lines (Koszinowski et al., 1986). The regulatory activity did not show promoter specificity, since MCMV early genes (B. Bühler, unpublished observation) as well as unrelated genes were activated. To answer the question whether transcriptional activation by pp89 is likely to occur by direct binding to DNA sequences, we examined the ability of MCMV ie1 products to interact with DNA. We

\footnotetext{
${ }^{1}$ To whom requests for reprints should be addressed.
}

demonstrate that (a) pp89 is not able to bind to DNA directly, (b) pp89-DNA interaction can be mediated by histones, and (c) pp89 binds to histones in the absence of DNA.

\section{MATERIALS AND METHODS}

Virus and cell culture

MCMV (mouse salivary gland virus, strain Smith, ATCC VR-194) was used for infection of BALB/C mouse embryo fibroblasts (MEF) as described by Keil et al. (1985).

\section{Radiolabeling of MEF}

Cells were infected (m.o.i. 20) in the presence of cycloheximide $(50 \mu \mathrm{g} / \mathrm{ml})$. Three hours p.i., cycloheximide was replaced by actinomycin $D(2.5 \mu \mathrm{g} / \mathrm{ml})$, and cells were labeled for $3 \mathrm{hr}$ with $80 \mu \mathrm{Ci} / \mathrm{ml}\left[{ }^{35}\right.$ S] methionine (Amersham, Braunschweig, FRG).

\section{Protein extraction}

Cell extracts were prepared according to Purifoy and Powell (1976). All procedures were done at $4^{\circ}$. MEF were suspended in lysis buffer, containing 20 $\mathrm{mM}$ Tris-hydrochloride, $\mathrm{pH} 7.5,2 \mathrm{mM} \beta$-mercaptoethanol, and $500 \mu \mathrm{g}$ of bovine serum albumin per milliliter at a cell concentration of $10^{7} / \mathrm{ml}$. The cells were disrupted by sonication $(4 \times 10 \mathrm{sec}$ at $100 \mathrm{~J} / \mathrm{sec}$, Braun Sonifer B-12) and an equal volume of high salt buffer was added to give final concentrations of $1.7 \mathrm{M}$ $\mathrm{NaCl}$ and $5 \mathrm{mM}$ EDTA. After a 40-min incubation, the lysate was cleared of DNA and protein precipitates by centrifugation at $30,000 \mathrm{~g}$ for $20 \mathrm{~min}$ and dialyzed 
overnight against binding buffer $(20 \mathrm{mM}$ Tris-hydrochloride, $\mathrm{pH} 7.5,50 \mathrm{mM} \mathrm{NaCl}, 1 \mathrm{mM}$ EDTA, $2 \mathrm{mM}$ $\beta$-mercaptoethanol, $10 \%$ glycerol). The precipitate formed during dialysis was discarded after centrifugation at $100,000 \mathrm{~g}$ for $1 \mathrm{hr}$. About $20 \%$ of labeled MCMV proteins were lost during the clearing of the lysates by centrifugation. This decrement was similar for all MCMV proteins. Extracts prepared from MEF infected (as described above) in the presence of cycloheximide and subsequent replacement by actinomycin D are referred to as IE extracts. Histones extracted from calf thymus were purchased from Sigma (Type II-AS).

\section{DNA cellulose chromatography}

Double-stranded DNA cellulose using either calf thymus DNA (Sigma, D 1501, Munich, FRG) or MCMV DNA was prepared according to Weissbach and Poonian (1974). Equimolar concentrations of plasmidcloned MCMV DNA fragments covering more than 95\% of the genome (Ebeling et al., 1983) served as a source of MCMV DNA. Plasmid pACYC 177 DNA was used as control. Single-stranded calf thymus DNA cellulose was prepared as described by Alberts and Herrick (1971). Cellulose (Whatman CF 11) was washed two times in $1 \mathrm{~N} \mathrm{HCl}$, rinsed extensively in $\mathrm{H}_{2} \mathrm{O}$, and dried in air. Phenol-extracted DNA (10 mg), suspended in $8 \mathrm{ml}$ of $10 \mathrm{mM} \mathrm{NaCl}$, was mixed with $1 \mathrm{~g}$ of cellulose, dried at $4^{\circ}$, and subsequently at $22^{\circ}$. After resuspension in ethanol, the mixture was cooled on ice and irradiated with light $\left(240 \mathrm{~nm}, 10^{5} \mathrm{ergs} / \mathrm{mm}^{2}\right) 10$ times for $1 \mathrm{~min}$. The siurry was washed three times in $1 \mathrm{mM}$ $\mathrm{NaCl}$ and spread out on filter paper to dry in air. Usually 8-13 $\mathrm{mg}$ of DNA could be bound to $1 \mathrm{~g}$ of cellulose. Calf thymus (CT) DNA cellulose was resuspended in 1 $\mathrm{mM} \mathrm{NaCl}(250 \mathrm{mg} / \mathrm{ml}$ column volume) and poured into $1-\mathrm{ml}$ tuberculin syringes sealed with glass wool. The columns were washed with 5 column vol of binding buffer and saturated with 1 vol of $0.2 \%$ BSA. Up to 2 $\mathrm{mg}$ of extracts per milliliter of column volume was passed through the DNA cellulose column by a constant flux of $4 \mathrm{ml} / \mathrm{cm}^{2} / \mathrm{hr}$ at $4^{\circ}$. Subsequently, the column was rinsed with 5 column vol of binding buffer. Proteins bound to DNA were eluted with 3 column vol of binding buffer with $\mathrm{NaCl}$ concentrations indicated.

\section{Chromatography on histone/DNA cellulose}

CT histones $(125 \mu \mathrm{g})$ were suspended in $6 \mathrm{ml}$ of binding buffer containing $100 \mathrm{mM} \mathrm{NaCl}$ and mixed with $0.5 \mathrm{ml}$ CT DNA cellulose, saturated with BSA as described above. After histone-DNA interaction at $4^{\circ}$ for $30 \mathrm{~min}$, columns containing different amounts of histone-CT DNA cellulose $(50$ to $200 \mu l)$ were pre- pared. Prior to chromatography of $I E$ extracts containing $30 \mu \mathrm{g}$ of protein, the columns were washed with 5 column vol of binding buffer adjusted to $100 \mathrm{mM} \mathrm{NaCl}$.

\section{Chromatography on histone-Sepharose}

Calf thymus histones (Type II-AS; Sigma) were coupled to CNBr-activated Sepharose 4B (Pharmacia) according to the instruction of the manufacturer. The histone-Sepharose was poured into tuberculin syringes and equilibrated with binding buffer. Protein extracts were passed through the column as described for DNA cellulose columns. Subsequentiy, the column was rinsed with 5 column vol of binding buffer. Histone-bound proteins were eluted with 3 column vol of binding buffer with the $\mathrm{NaCl}$ concentrations indicated and buffers containing $1 \mathrm{M}$ ammonia were supplemented with the concentrations of guanidine hydrochloride indicated. Eluates containing ammonia and guanidine hydrochloride were adjusted to $\mathrm{pH} 7$ with a $4 \mathrm{MNaH}_{2} \mathrm{PO}_{4}$ buffer prior to immunoprecipitation.

\section{Radioimmunoprecipitation}

MCMV-specific antiserum was prepared by injection of female BALB/C mice at the age of 4-6 weeks with $10^{5}$ PFU of partially purified MCMV. Mice were injected three times at intervals of 2 weeks. The serum was taken 14 days after the last boost. Immunoprecipitation, SDS-polyacrylamide gel electrophoresis, and fluorography were carried out as described previously (Keil et al, 1985).

\section{Quantification of immunoprecipitated proteins}

To quantify the amounts of immunoprecipitated proteins, autoradiographs after different times of exposure were scanned with an LKB UltraScan unit.

\section{RESULTS}

\section{Affinity of IE proteins to CT DNA}

Proteins interacting with DNA can be isolated and characterized by DNA cellulose chromatography. Under low-salt conditions, proteins with low affinity for DNA pass through the column, whereas DNA-binding proteins are retained. Bound proteins are recovered, depending on their affinity for DNA, by elution with buffers containing an elevated salt concentration. ${ }^{35}$ S]methionine-labeled IE extracts were chromatographed on CT DNA cellulose, and IE proteins in eluates were visualized by immunoprecipitation and fluorography (Fig. 1). This procedure was necessary to identify IE proteins, since MCMV infection does not shut off cellular protein synthesis. In the nonbinding fraction, $p p 89$, pp76, a cleavage product of pp89 gen- 


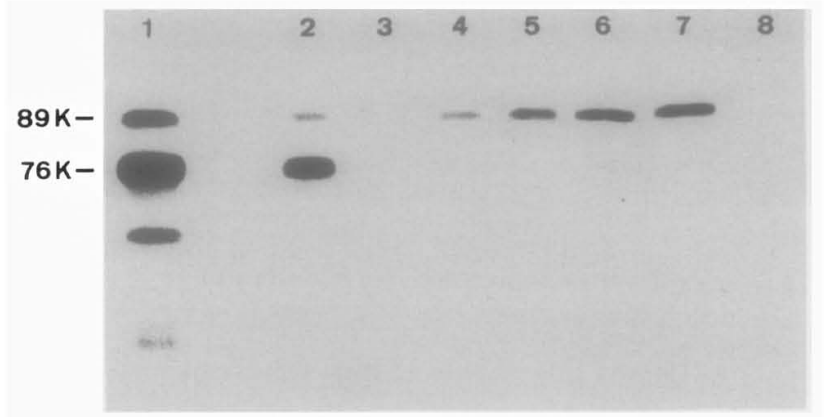

FIG. 1. DNA affinity chromatography of IE proteins. $\left[{ }^{35}\right.$ S $]$ methionine-labeled IE extracts were applied to CT DNA cellulose. Nonbound proteins were eluted with binding buffer (lane 1), bound proteins were eluted stepwise with $0.1,0.15,0.2,0.3,0.4,0.6$, and $1 M$ $\mathrm{NaCl}$ (lanes 2 to 8). Eluted IE proteins were immunoprecipitated with murine antiserum to MCMV and subjected to gel electrophoresis and fluorography. One-tenth of the nonbound proteins and the whole eluates of elevated $\mathrm{NaCl}$ concentrations were used for immunoprecipitation. The molecular masses of IE proteins are indicated.

erated by a cellular protease (Keil et al., 1985), and additional smaller proteins which are antigenically related to pp89 were also found, with pp76 being most abundant (lane 1). DNA-bound pp76 was eluted at 0.1 $M \mathrm{NaCl}$ (lane 2), whereas pp89 was retained until 0.3 to $0.6 \mathrm{M} \mathrm{NaCl}$, indicative of a higher affinity for DNA (lanes 3 to 7). Additional experiments showed that (a) cellulose columns lacking DNA did not retain IE proteins, (b) chromatography on columns containing single-stranded calf thymus DNA revealed a similar distribution of DNA-bound and -unbound IE proteins, and (c) omission of the cycloheximide/actinomycin $D$ reversal prccedure resulted in less IE proteins with otherwise identical properties. Scanning of autoradiographs revealed that about $10 \%$ of pp89 and $5 \%$ of pp76 was retained by DNA under these conditions.

\section{Cellular factors are required for pp89-DNA interaction}

The presence of the bulk of IE proteins in the DNAnonbinding eluate (see Fig. 1) could be due to different reasons. First, pp89 could be heterogeneous with regard to DNA-binding capacity. Second, the interaction of pp89 with DNA could be indirect and dependent upon cellular factors representing the limiting constituents in the cell extract. To test the first possibility, DNA-bound pp89 eluted at $0.6 \mathrm{M} \mathrm{NaCl}$ was dialyzed against binding buffer and rechromatographed on CT DNA celiulose. The complete elution of pp89 within the DNA-nonbinding fraction, unless cellular DNAbinding proteins were added, was suggestive of the latter alternative. Therefore, IE proteins eluting within the DNA-nonbinding eluate were reconstituted with cellular proteins (Fig. 2). Extracts of mock-infected MEF were separated by CT DNA cellulose chromatography into a DNA-binding and -nonbinding fraction. Both fractions were separately mixed with nonbinding IE eluates prior to chromatography on CT DNA cellulose. Addition of cellular DNA-binding proteins resulted in effective retention of pp89 proteins by CT DNA (lane 3), whereas the nonbinding cellular fraction had no effect (lane 4). These results argued against an intrinsic DNA-binding capacity of pp89 and demonstrated that cellular DNA-binding factors can mediate pp89-DNA interaction.

\section{Cellular factors that mediate pp89-DNA interaction have a high affinity for DNA}

To screen for the cellular factors involved in pp89DNA interaction, cellular DNA-binding proteins were fractionated according to their affinity for DNA. As a first step, extracts of mock-infected cells were loaded on several CT DNA cellulose columns, and DNA-binding proteins were eluted using a different $\mathrm{NaCl}$ concentration for each individual column. Subsequently, all columns were equilibrated with binding buffer. As a second step, the presence of the factors mediating

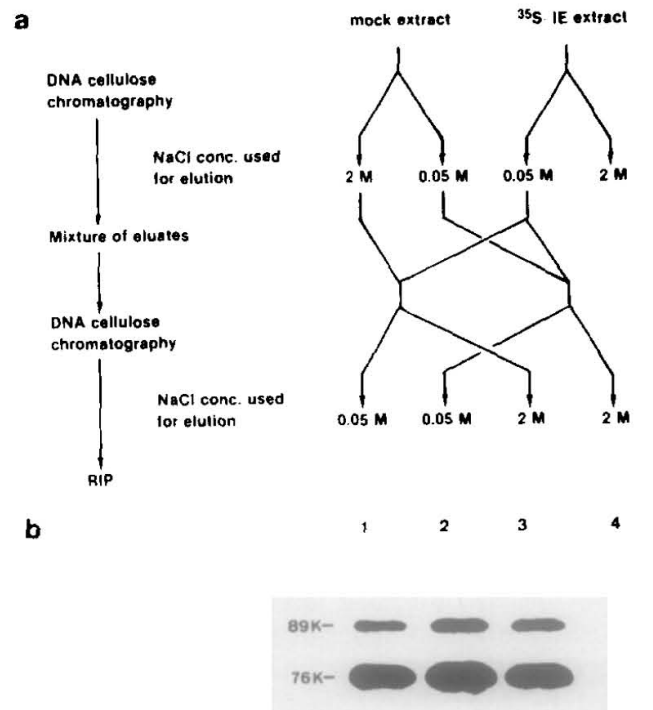

FIG. 2. Cellular factors can mediate association of IE proteins with DNA. (a) Experimental protocol. Extracts of mock-infected ceils and ${ }^{35}$ S]methionine-labeled IE extracts were chromatographed on CT DNA cellulose. Nonbound proteins were eluted with binding buffer and bound proteins with $2 \mathrm{M} \mathrm{NaCl}$. The $2 \mathrm{M} \mathrm{NaCl}$ eluate of mock extract was subsequently dialyzed against binding buffer. The 0.05 $M \mathrm{NaCl}$ eluate of the IE extract $(50 \mu \mathrm{g})$ was mixed with either $200 \mu \mathrm{g}$ of the $0.05 \mathrm{M} \mathrm{NaCl}$ eluate or $200 \mu \mathrm{g}$ of the $2 \mathrm{M} \mathrm{NaCl}$ eluate of the mock extract and chromatographed on CT DNA cellulose as described above. (b) Fluorography of IE proteins immunoprecipitated after DNA cellulose chromatography of eluate mixtures. 
pp89-DNA interaction was tested. For this purpose, a standard amount of a nonbinding IE eluate was loaded onto each of these columns, and bound IE proteins were eluted with $1 \mathrm{M} \mathrm{NaCl}$ and immunoprecipitated (Fig. 3a). It was expected that in the presence but not in the absence of these factors pp89 could be retained. Cellular factors which allowed binding of pp76 were already eluted at an ionic strength higher than $0.05 \mathrm{M} \mathrm{NaCl}$ (lanes 3 to 8), whereas factors which permitted binding of pp89 remained associated with DNA at $1 \mathrm{M} \mathrm{NaCl}$ (lane 7) and were eluted with $2 \mathrm{M}$ $\mathrm{NaCl}$ (lane 8). As a third step, to further characterize these cellular factors, the proteins eluting between 1 and $2 \mathrm{M} \mathrm{NaCl}$ were electrophoretically separated and silver-stained (Fig. 3b). Only four proteins with apparent molecular masses between $12.5 \mathrm{~K}$ and $17 \mathrm{~K}$ could be detected. DNA affinity and electrophoretic mobility of these proteins are the same as those described for core histones (Ohlenbusch et al., 1967). pp89 bands in lanes 4 and 6 are less prominent. This variation in the amount of eluted proteins is explained by the fact that in this experiment each lane represents the immunoprecipitates of proteins eluted from separate columns. This protocol is different than the stepwise elution profiles from a single column as shown in the experiment depicted in Fig. 1.

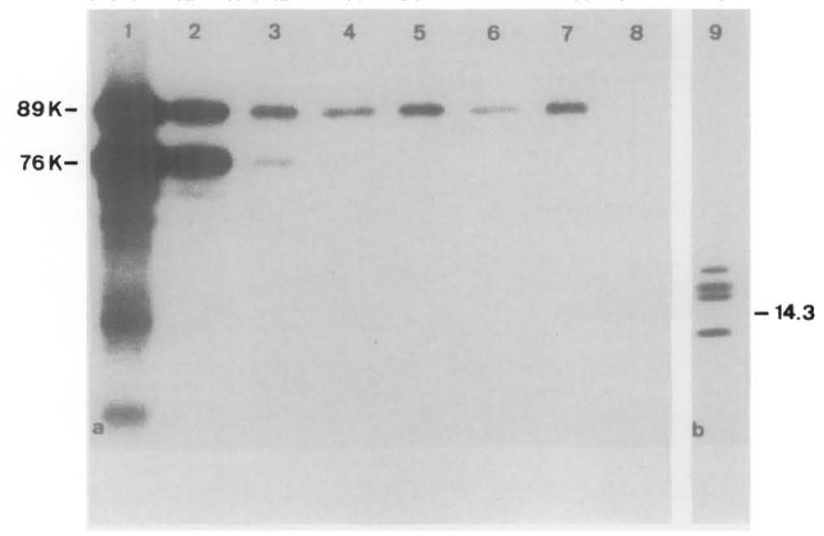

FIG. 3. DNA affinity of cellular factors involved in interaction of pp89 with DNA. Extracts of mock-infected cells $(1.5 \mathrm{mg})$ were applied to $1-\mathrm{ml}$ CT DNA cellulose columns, and proteins were eluted by rinsing with binding buffer containing different concentrations of $\mathrm{NaCl}$. After equilibration of columns with binding buffer, nonbinding eluates of IE extracts were chromatographed. Nonbinding IE proteins were washed out, and retained proteins were eluted with $1 \mathrm{M}$ $\mathrm{NaCl}$ and immunoprecipitated. (a) Fluorography of immunoprecipitated IE proteins. Lane 1, nonbinding IE extract used for chromatography. Lanes 2 to 8 , DNA-bound proteins from columns loaded with mock extracts and eluted with $0.05,0.1,0.2,0.4,0.6,1$, and $2 M$ $\mathrm{NaCl}$, respectively, prior to chromatography of IE extracts. (b) Silverstained cellular DNA-binding proteins eluted with $2 \mathrm{M} \mathrm{NaCl}$ after rinsing the column with $1 \mathrm{M} \mathrm{NaCl}$.

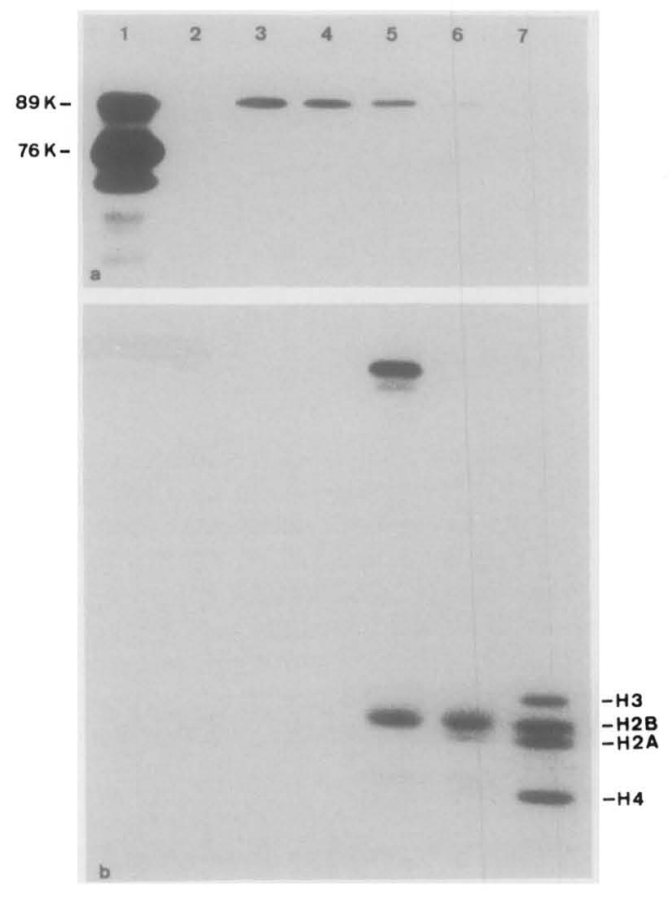

Fig. 4. Core histones support pp89-DNA interaction. DNA-nonbinding eluates of $\mathrm{IE}$ extracts adjusted to $0.1 \mathrm{M} \mathrm{NaCl}$ were loaded onto a DNA cellulose column ( $100 \mu$ l column volume) supplemented with histones. Nonbinding proteins were eluted with binding buffer containing $0.1 \mathrm{M} \mathrm{NaCl}$, and bound proteins were eluted stepwise by raising the $\mathrm{NaCl}$ concentration from $0.2,0.3,0.4,0.6$, or 1 to $2 \mathrm{M}$ $\mathrm{NaCl}$ (lanes 2 to 7). (a) Fluorography of IE proteins precipitated with murine antiserum to MCMV. (b) Silver-stained proteins from eluates precipitated with $10 \%$ trichloroacetic acid and subjected to gel electrophoresis.

\section{Core histones can support pp89-DNA interaction}

To confirm the putative role of histones in pp89DNA interaction, CT DNA cellulose was loaded with histones. In order to selectively bind pp89, a nonbinding IE eluate adjusted to $0.1 \mathrm{M} \mathrm{NaCl}$ was passed through the column (Fig. 4a). As expected, pp76 and the IE proteins with higher electrophoretic mobility were not adsorbed (lane 1). Bound pp89, however, could be recovered from the salt elution steps between 0.3 to $0.6 \mathrm{M} \mathrm{NaCl}$ (lanes 3 to 5), and a low amount of pp89 was eluted at $1 \mathrm{M} \mathrm{NaCl}$ (lane 6). The same results were obtained with CT DNA loaded with murine histones (not shown). There was no difference between the elution profiles of IE proteins using either IE extracts for chromatography on CT DNA cellulose or nonbinding IE eluates for chromatography on CT DNA cellulose supplemented with histones (compare Fig. 1 and Fig. 4a). The DNA-bound histones dissociated at the salt concentrations described for core histones (Ohlenbusch et al., 1967) (Fig. 4b). 
Although core histones are expected to represent abundant cellular proteins in extracts obtained by treatment of sonicated cells with $1.7 \mathrm{M} \mathrm{NaCl}$, only a small fraction of pp89 could be detected to associate with DNA (see Fig. 1). We found, however, that core histones, although solubilized during the high-salt extraction procedure, were almost completely removed during the subsequent dialysis and $100,000 \mathrm{~g}$ centrifugation steps. We therefore reasoned that the limiting amount of histones was not sufficient to achieve complete retention of pp89. Histone-supplemented CT DNA cellulose columns of different bed volumes were therefore used for chromatography of a nonbinding IE eluate (Fig. 5). Binding of pp89 to DNA was found to be directly proportional to the amount of histones on the columns (lanes 4, 6, and 8). The 200- $\mu$ I DNA cellulose column loaded with $50 \mu \mathrm{g}$ histones retained almost completely the pp89 (lanes 7 and 8). Under these conditions, also pp76 remained bound, but a difference between pp89 and pp76 retention was still visible. There was no binding of pp89 to a DNA cellulose column lacking histones (lane 2).

\section{Interaction of IE proteins with MCMV DNA requires histones}

To investigate whether the interaction of IE proteins with MCMV DNA differs from the interaction with calf thymus DNA, chromatography on MCMV DNA cellulose was carried out.

As has been observed by chromatography on CT DNA cellulose, only pp89 was retained by the MCMV DNA column and was eluted at $\mathrm{NaCl}$ concentrations between 0.3 and $0.6 \mathrm{M}$ (Fig. 6a). The DNA in these columns contained about $20 \%$ of pACYC 177 . Columns containing only the vector DNA gave the same results (not shown). Thus, MCMV DNA sequences influence neither the preference of pp89 for interaction with DNA nor its affinity for DNA. To prove that the interaction with MCMV DNA is also dependent on his-

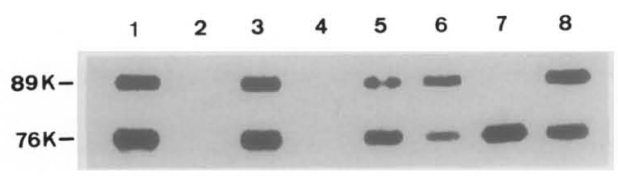

FIG. 5. Histone concentration-dependent interaction of $p p 89$ with DNA. DNA-nonbinding eluates of IE extracts adjusted to $0.1 \mathrm{M} \mathrm{NaCl}$ were loaded onto a DNA cellulose column ( $200 \mu$ l, lanes 1 and 2) or onto histone-DNA cellulose columns of different column volumes (lanes 3 and 4,50 $\mu \mathrm{l}$; lane 5 and 6, $100 \mu \mathrm{l}$; lanes 7 and 8, $200 \mu \mathrm{l}$ ). Nonbinding proteins were eluted with binding buffer containing 0.1 $M \mathrm{NaCl}$ (lanes 1, 3, 5, and 7), and bound proteins were eluted with 1 $\mathrm{M} \mathrm{NaCl}$ (lanes 2, 4, 6, and 8). IE proteins were immunoprecipitated and subjected to fluorography.
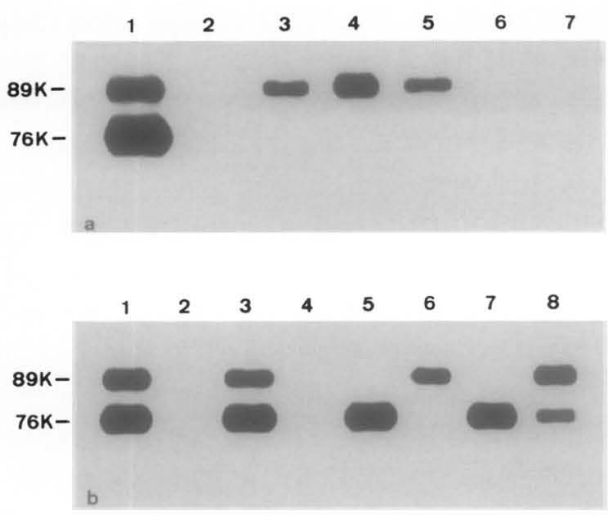

FiG. 6. Affinity of IE proteins for MCMV DNA. MCMV DNA cloned with Hindlll by insertion of the fragments into the Hindlll site of the plasmid vector pACYC 177, as described previously (Ebeling et al., 1983), was attached to cellulose at a stoichometrical relation of the fragments. Preparation of DNA cellulose and chromatography were done as described for CT DNA cellulose. (a) Chromatography of IE extracts was done as described in Fig. 1. Bound proteins were eluted with $0.2,0.3,0.4,0.6,1$, and $2 \mathrm{M} \mathrm{NaCl}$ (lanes 2 to 7). (b) Histone concentration-dependent interaction of IE proteins with MCMV DNA. Chromatography was carried out as described in Fig. 5 .

tones, a nonbinding IE eluate was chromatographed on MCMV DNA columns supplemented with histones as described in legend to Fig. 5. Binding of pp89 to MCMV DNA was again found to be directly proportional to the amount of histones on the columns (Fig. $6 \mathrm{~b}$, lanes $4,6,8$ ). We therefore concluded that binding of pp89 to MCMV DNA also requires the presence of core histones.

\section{IE proteins have a high affinity for histones coupled to Sepharose}

To determine whether histone-DNA interaction is a prerequisite for binding of IE proteins to histones, IE extracts were chromatographed on a histone-Sepha-

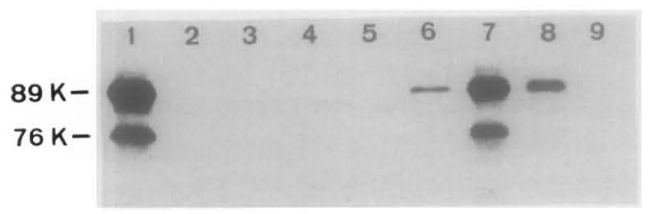

FIG. 7. Affinity of IE proteins for histones coupled to Sepharose. $\left[{ }^{35}\right.$ S]methionine-labeled IE extracts were applied to histone-Sepharose. Nonbound proteins were eluted with binding buffer (lane 2), bound proteins were eluted stepwise with binding buffer containing $0.5,1$, and $2 \mathrm{M} \mathrm{NaCl}$ (lanes 3 to 5) and subsequently with $1,2,4$, and $6 \mathrm{M}$ guanidine hydrochloride in $1 \mathrm{M}$ ammonia (lanes 6 to 9). Eluted IE proteins were immunoprecipitated and subjected to gel electrophoresis and fluorography. Lane 1, immunoprecipitated IE proteins of extract used for chromatography. 
rose column (Fig. 7). Bound proteins were eluted with $0.5,1$, and $2 \mathrm{M} \mathrm{NaCl}$ (lanes 3 to 5). Seventy percent of the labeled proteins passed through the column at 0.1 $\mathrm{MNaCl}$ (lane 2), and further 12, 10, and $1 \%$ of labeled material eluted with $0.5,1$, and $2 M$, respectively. Immunoprecipitates of these eluates did not contain IE proteins. Only after rinsing the column with $1,2,4$, and $6 \mathrm{M}$ guanidine hydrochloride in $1 \mathrm{M}$ ammonia could IE proteins be recovered (lanes 6 to 9). No binding of IE proteins to Sepharose in the absence of histones was detectable (not shown). These results demonstrate that IE proteins can bind to histones also in the absence of DNA. Second, in the absence of DNA IE proteins bind to histones with a very high affinity (see Fig. 4 for comparison).

\section{DISCUSSION}

The major IE protein pp89, the product of the iel gene in transcription unit ie1 of MCMV, is predominantly located in the nucleus of infected cells (Keil et al., 1985, 1987a,b). A fraction of the polypeptide is probably processed and transported to the plasma membrane, where it is detected by specific cytolytic $T$ lymphocytes (Koszinowski et al., 1987a,b; Reddehase et al. 1986). We have reported previously that pp89 trans-activates viral genes without apparent promoter specificity (Koszinowski et al., 1986). In order to analyze the molecular mechanism leading to this indiscriminate transcriptional activation, we have studied the DNA-binding capacity of pp89 by CT DNA cellulose chromatography.

The results demonstrated that the interaction of pp89 with cellular or MCMV DNA depends upon cellular factors. First, chromatography of cell extracts at $0.05 \mathrm{M} \mathrm{NaCl}$ resulted in separation of IE proteins into a DNA-bound and -nonbound fraction. Second, rechromatography of bound pp89, after elution at $0.6 \mathrm{MNaCl}$ and dialysis against binding buffer, revealed no DNAbinding activity. Third, addition of cellular DNA-binding proteins to the nonbinding fraction restored pp89DNA interaction. The auxiliary cellular factors have a very high affinity for DNA and an electrophoretic mobility known for core histones. Fourth, direct evidence for a role of core histones in pp89--DNA interaction was obtained by using purified histones. Thus, pp89 is apparently unable to interact with DNA in the absence of auxiliary cellular factors.

We analyzed whether interaction of pp89 with histones can be correlated with a structural property. A significant homology of the nucleotide and the amino acid sequence of $p p 89$ with the respective sequences of histone $\mathrm{H} 2 \mathrm{~B}$ was found (Keil et al., 1987b). Between amino acids 96 and 153 of pp89 and amino acids 27 and 87 of the histone $\mathrm{H} 2 \mathrm{~B}$ an identical core sequence of 7 amino acids is flanked by sequences where 17 of 56 amino acids are identical and located at corresponding positions. The codons for these 23 identical amino acids display $83 \%$ identity, whereas only $48 \%$ homologous nucleotides would be required to encode these amino acids. The similarity within this region increases to $62 \%$ when conservative amino acid exchanges are considered as similar. The region between residues 37 and 114 of $\mathrm{H} 2 \mathrm{~B}$ is important for the interaction of $\mathrm{H} 2 \mathrm{~B}$ with histone $\mathrm{H} 2 \mathrm{~A}$ (Isenberg, 1979; Kedes, 1979). We therefore propose that amino acids 96 to 153 of pp89 play a role in the interaction of pp89 with histones. This property of pp89 is unique compared to other herpesviral regulatory $I E$ proteins.

Mainly pp89 and less efficiently the proteolytic cleavage product $p p 76$ and the minor ie1 products were retained by histones on CT DNA columns at salt concentrations exceeding $0.1 \mathrm{M} \mathrm{NaCl}$. All these proteins are antigenically related, because monoclonal antibody $6 / 20 / 1$ binds to all of them (Keil et al., 1985). The epitope detected by mAb 6/20/1 maps to amino acids around position 480 in the C-terminal region of pp89 (M. Messerle, to be published). This epitope is located in a glutamic acid-rich region (positions 396-532) containing 33\% acidic amino acids. Glutamic acid-rich peptides and glutamic acid-rich domains of the high-mobility group chromosomal proteins are known to interact with histones (Einck and Bustin, 1985; Stein et al., 1979). Such sequences probably contribute affinity of pp89 and $p p 76$ for histones, but do not explain the different affinity of $p p 89$ and pp76. The C-terminal amino acids 589 to 595 represent a nuclear transport signal (Keil et al., 1987b). Since pp76 is still transported to the nucleus (Keil et al., 1985), pp89 is perhaps cleaved in the $\mathrm{N}$-terminal region resulting in $p p 76$. Cleavage in this region is very likely to affect the sequence homologous to $\mathrm{H} 2 \mathrm{~B}$.

The affinity of IE proteins to histones either bound to DNA or directly coupled to Sepharose differed considerably. On DNA columns supplemented with histones mainly pp89 was retained and could be eluted at ionic strengths of 0.3 to $0.6 \mathrm{M} \mathrm{NaCl}$. On columns with histones directly coupled to Sepharose, both pp89 and $p p 76$, were retained, and binding was still resistant to an $\mathrm{NaCl}$ concentration of $2 \mathrm{M}$. We do not yet understand these remarkable differences in affinity. Two explanations can be offered: First, interaction of histones with DNA could limit the access of other proteins to histone domains involved in DNA binding, whereas histones coupled to Sepharose could still expose these domains. Second, binding of histones to DNA 
cellulose possibly results in formation of nucleosome complexes, which makes domains involved in histone/histone interaction inaccessible to interaction with other proteins. The glutamic acid-rich regions shared by pp89 and pp76 perhaps interact with histone regions rich in basic amino acids and contribute to the very high affinity of IE proteins to histones coupled to Sepharose. If the high affinity of the IE proteins for isolated histones in vitro reflects the capacity of these proteins to prevent nucleosomal packaging of DNA in vivo, an important biological role of this relation could be considered. The interaction of the IE proteins with the individual histone proteins is under study.

Other herpesviral IE proteins, as the products of the IE 1 and IE2 genes of human CMV (Tevethia and Spector, 1984; Hermiston et al., 1987), the IE protein of pseudorabies virus (Green et al., 1983), and the ICP4 and ICPO of herpes simplex virus (Everett, 1984; O'Hare and Hayward, 1985) share the property of pp89 to stimulate transcription. The DNA-binding activities of ICP4 have been characterized in detail. Chromatography of cell extracts on CT DNA revealed DNA binding of the protein (Hay and Hay, 1980), and dissociation was found at $0.3 \mathrm{M} \mathrm{NaCl}$ (Bookout and Levy, 1980). Freeman and Powell (1982) reported that partially purified ICP4 was not able to associate with single-stranded CT DNA unless supplemented with cell extracts. Whether binding of ICP4 to a doublestranded DNA is also dependent upon cellular factors is not known. Recently, specific binding sites of ICP4 on plasmid pBR322 and HSV gD promoter sequences have been identified by Faber and Wilcox (1986). Binding to HSV $\alpha-0, \alpha-4$, and $\gamma$ promoter sequences have been demonstrated by Kristie and Roizman (1986a,b). In both studies, however, binding by ICP4/cellular factor complexes was not excluded.

Our results demonstrate that pp89 requires histones to interact with DNA. It is not yet excluded, however, that the binding of $p p 89$ to histones exposes an intrinsic DNA-binding activity of pp89 involved in stimulation of transcription. Experiments to examine this possibility using purified pp89 supplemented with histones are under way.

\section{ACKNOWLEDGMENTS}

This study was supported by Grant Ko $571 / 8$ from the Deutsche Forschungsgemeinschaft to Uirich $\mathrm{H}$. Koszinowski. We thank $\mathrm{H}$. Riehle and $M$. Votteler for technical assistance and S. Grau for manuscript preparation.

\section{REFERENCES}

ALBERTS, B., and HERRICK, G. (1971). DNA cellulose chromatography. In "Methods in Enzyrnology" (S. P. Colowick and N. O. Kaplan, (Eds.), Vol 21, pp. 198-217. Academic Press, New York.
BookOUT, J. B., and LEV. C. C. (1980). Comparative examination of the polypeptides of herpes simplex virus: Types 1 and 2. Virology $101,198-216$.

Ebeung, A., Keil, G. M., KNust, E, and Koszinowski, U. H. (1983). Molecular cloning and physical mapping of murine cytomegalovirus DNA. J. Virol. 47, 421-433.

EINCK, L. and BUSTIN, M. (1985). The intracellular distribution and function of the high mobility group chromosomal proteins. Exp. Cell Res. 156, 295-310.

EVERETT, R. D. (1984). Trans-activation of transcription by herpes virus products: Requirement for two HSV-1 immediate-early polypeptides for maximum activity. EMBO J. 3, 3135-3141.

FABER, S. W., and WiLCOX, K. W. (1988). Association of the herpes simplex virus regulatory protein $1 C P 4$ with specific nucleotide sequences in DNA. Nucleic Aciots Res. 14,6067-6083.

FREEMAN, M. J., and POWELL, K. L. (1982). DNA-binding properties of a herpes simplex virus immediate early protein. J. Virot. 44 , $1084-1087$.

Green, M. R., Treisman, R., and Maniatis, T. (1983). Transcriptional activation of cloned human $\beta$-globin genes by viral immediate early gene products. Cell 35, 137-148.

HAY, R. T., and HAY, J. (1980). Properties of herpesvirus-induced "immediate-early" polypeptides. Virology 104, 230-234.

HeRMISTON, T. W., MALONE, C. L., WITTE, P. R., and STINSKl, M. F. (1987). Identification and characterization of the human cytomegalovirus immediate-early region 2 gene that stimulates gene expression from an inducible promoter. J. Virol. 61, 3214-3221.

ISENBERG, I. (1979). Histones Annu. Rev. Biochem. 48, 159-191.

KEDES, L. H. (1979). Histone genes and histone messengers. Annu. Rev. Biochem. 48, 837- 870 .

KEIL, G. M., Ebeling-Keil, A., and Koszinowski, U. H. (1984). Temporal regulation of murine cytomegalovirus transcription and mapping of viral RNA synthesized at immediate early times after infection. J. Virol. 50, 784-795.

Keil, G. M., Ebeling-KelL, A., and Koszinowski, U. H. (1987a), immediate-early genes of the murine cytomegalovirus: Location, transcripts, and translation products. J. Virol $61,526-533$

Kell, G. M., Ebeling-Kell, A., and Koszinowski, U. H. (1987b). Sequence and structural organization of the immediate-early gene / of murine cytomegalovirus. J. Virol. 61, 1901-1908.

KEIL, G. M., FibI, M. R., and Koszinowski, U.H. (1985). Characterization of the major immediate-early polypeptides encoded by murine cytomegalovirus. I. Virol. 54, 422-428.

Koszinowski, U. H. KeIL, G. M., SChwarz, H., SCHICKedanz, I., and REDDEHASE, M. J. (1987b). A nonstructural polypeptide encoded by immediate-early transcription unit 1 of murine cytomegalovirus is recognized by cytolytic $T$ lymphocytes. 1 . Exp. Med. 166, $289-294$

KOSZINOWSKl, U. H. KEIL, G. M., VOLKMER, H., FlBi, M. R., EBELING$\mathrm{KEL}, \mathrm{A}$, and $\mathrm{MUNCH}, \mathrm{K} .(1986)$. The $89,000-\mathrm{M}$, murine cytomegalovirus immediate-early protein activates gene transcription. J. Virol. 58, 59-66.

KoszinOWSKI, U. H., REdoehase, M. J., KeIL, G. M., and SChickEdANZ, J. (1987a). Host immune response to cytomegalovirus: Products of transfected viral immediate-early genes are recognized by cloned cytolytic T lymphocytes. /. Virol. 61, 2054-2058.

KRISTIE, T. M., and RoIzMAN, B. (1986a). $\alpha 4$, the major regulatory protein of herpes simplex virus type 1 , is stably and specifically associated with promoter-regulatory domains of $\alpha$ genes and of selected other viral genes. Proc. Natl. Acad. Sci. USA 83, 3218-3222.

KRISTIE, T. M., and ROIZMAN, B. (1986b). DNA-binding site of the major regulatory protein $\alpha 4$ specifically associated with pro. 
moter-regulatory domains of $\alpha$ genes of herpes simplex virus type 1. Proc. Natl. Acad. Sci. USA 83, 4700-4704.

O'HARE, P., and HAYWARD, G. S. (1985). Evidence for a direct role for both the 175,000-AND 110,000-molecular-weight immediateearly proteins of herpes simplex virus in the trans-activation of delayed-early promoters. J. Virol 53, 751-760.

Ohlensusch, H. H., Olivera, B. M., Tuan, D., and Davidson, N. (1967). Selective dissociation of histones from calf thymus nucleoprotein. J. Mol. Biol. 25, 299-315.

PURIFOY, D. J.M., and POWELL, K. L. (1976). DNA-binding proteins by herpes simplex virus type 2 in HEp-2 cells. J. Virol. 19, 717--731.

RedDehAse, M. J., BOHRING, H.-J., and KosZinowski, U. H. (1986). Cloned long-term cytolytic T-lymphocyte line with specificity for an immediate-early membrane antigen of murine cytomegalovirus. $)$ Virol. 57, 408-412.
Rigby, P. W. J., Dieckman, M., Rhodes, C., and Berg, P. (1977). Labeling deoxyribonucleic acid to high specific activity in vitro by nick translation with DNA polymerase 1. J. Mol. Biol. 113, $237-251$

STEIN, A., WhTLLock, J. P., JR., and BINA, M. (1979). Acidic polypeptides can assemble both histones and chromatin in vitro at physiological ionic strength. Proc. Natl. Acad. Sci. USA 76, 5000-5004.

TEVETHIA, M. J., and SPECTOR, D. J. (1984). Complementation of an adenovirus 5 immediate early mutant by human cytomegalovirus. Virology 137, 428-431.

Weissbach, A., and POONIAN, M. (1974). Nucleic acids attached to solid matrices. In "Methods in Enzymology" (W. B. Jakoby and $M$. Wilcheck, Eds.), Vol. 34, pp. 463-475, Academic Press, New York. 